\title{
Non-applicability of Prescription to War Crimes during Iraq's War against Iran
}

\author{
Seyed Rasoul Ghorishi ${ }^{1}$, Sabber Niavarani ${ }^{1,2}$ \& Seyed Ghasem Zamani ${ }^{1,3}$ \\ ${ }^{1}$ Department of Law, Najafabad Branch, Islamic Azad University, Najafabad, Iran \\ ${ }^{2}$ Department of Public and International Law, Science and Research Branch, Islamic Azad university, Tehran, \\ Iran \\ ${ }^{3}$ Department of Public and International Law, Allameh Tabatabai University, Tehran, Iran \\ Correspondence: Sabber Niavarani, Department of Law, Najafabad Branch, Islamic Azad University, Najafabad, \\ Iran. E-mail: Sabberniavarani@gmail.com
}

Received: April 27, 2016 Accepted: May 10, 2016 Online Published: June 29, 2016

doi:10.5539/jpl.v9n5p65 URL: http://dx.doi.org/10.5539/jpl.v9n5p65

\begin{abstract}
International responsibility of Iraq regarding imposed war against Iran and compensating all harms has been an issue attracted public attention in Iran; in a way that sometimes it has been discussed. Nevertheless, it should not be ignored that this war happened long time ago, thus it involves the issue of Prescription or Statutory Limitations. Since the Statutory Limitation often is the main obstacle facing the culture of non-punishment, the main question is that whether Iraqi's war crimes is supposed to prescription?

It should be noted that prominent values of humanity entail the condemning of severe international crimes and non-applicability of principle of prescription. Therefore, International Criminal Law through codification of regional and international documents including the Supreme Iraqi Criminal Tribunal has predicted a period of 35 years for investigation of Iraqi high-ranking officials' crimes: Accordingly, it seems that the theory of non-applicability of prescription over Iraqi's war crimes during war against Iran has been substantiated.
\end{abstract}

Keywords: prescription, Iraq, Iran, war crimes, supreme criminal tribunal

\section{Introduction}

Unfortunately, war between states has been a considerable fact of international life so that wars have been raised with states (Paenson, 1982, P. 2). At first, human tends to prevent from war then investigates different solutions in order to limit effects of war due to the inevitability of war (Noorbaha, 1992-1993, P. 176). Nevertheless, legal illegitimacy of war was confirmed along with codification of United Nation charter at the end of World War II. The experiences and facts ruling on actors' relationships within international community have indicated that legal system is not a definite obstacle for aggressive policies of some states. Iraq's invasion against Iran in 1980 is a sample of these policies obviously or hidey supported by different countries as pacifists in modern world. Iraq started to attack Iran through sporadic actions at 20 April 1980 (Hiom, 1997, P. 54), expanded at 22 September 1980 through a plan (Parsadoost, 1992, P. 17), and based on the various reasons (Doroodoian, 1997, P. 54) while the start of invasion declared at 22 September from the view of international community (Zamani, 2002, P. 43). Undoubtedly, this aggressive attack was planned in advance (Dekker, 1992, P. 258), but Security Council avoided considering this attack as a threat toward international peace and security although the invasion was thoroughly supervised. From the perspective of Security Council, the continuation of attack was only considered as a possibility to endanger peace and security. Security Council described the war under the title of "situation between Iran and Iraq" in order not to determine the aggressor in imposed war. Every fair person would consider the reason for eight-year continuation of war between Iran and Iraq as unreasonable reaction of Security Council. After the end of war and acceptance of Resolution $598^{1}$ by parties, the issue of responsibility of Iraqi state and committed war crimes by Iraq during the war was more important for Iran because Iraq committed various war crimes including murder, torture, and inhuman treatment with persons protected by the Geneva Conventions, extensive destruction and arbitrarily confiscation of property. There were also some cases

\footnotetext{
${ }^{1}$ Security Council Documents, Res/598, 20 July 1987.
} 
including violated rules and practicable norms in international armed conflict such as intentional directing of attacks against civilian population without any participation in conflicts, intentional directing of attacks against civilian purposes with no military nature, attacks and bombardment of towns, villages, facilities and buildings that were undefended out of military purposes; destruction or seizure of property, looting towns and villages and use of suffocating gases, chemicals, poisonous or other gases and prohibited substances, etc. (Siah Rostami, 2004, P. 212). The considered point by Iraqi and non-Iraqi jurists and politicians is that there is a long passage of time from the end of war and ceasefire between parties and it is claimed by them that war crimes of Iraq against Iran involves Statutory Limitations so that they cannot be reconsidered again. Because Statutory Limitation ${ }^{2}$ is a legal foundation existed in national and international system of course, the role of these systems is not equal in acceptance and applying this expression. The expression of Statutory Limitations has been more considered in national systems than international systems. Statutory Limitations exists in both legal and criminal issues. Statutory Limitations in criminal issues includes time lapse of compliant, sentencing and punishment implementation. This establishment is not perfectly considered in international law while it is more considered in domestic systems (Quoc Dinh, Daillier et peller, 1994, P. 34). The reason is related to the severe reaction of international community towards the most aggressive actions in frame of criminalization and description of these actions as international crimes. In this regard, some documents such as Convention on the non-applicability of statutory limitations to war crimes and crimes against humanity, 1968; European Convention on the non-applicability of Statutory Limitations to crimes against humanity and war crimes, 1974 and Statue of International Criminal Court (ICC), 1998 have been approved with high effect on development of international criminal law (Haddadi, 2006, P. 125). In this regard, Iraqi Special Tribunal was established by occupying power to trail the leaders of Baath then the mentioned trial's name changed to Supreme Iraqi Criminal Tribunal based on the confirmation of temporary states through adopted statue of Parliament. Although it was necessary for an international, combined or a domestic tribunal to prosecute crimes of Saddam and members of Baath, but Statue of this tribunal including Article 1 Clause (2) considers Statutory Limitations and time jurisdiction of tribunal predicting time duration of 35 years from 17 July 1968 to 1 May 2003; hence, criminalization of committed crimes during this time including war crimes, crimes against humanity, genocide and violation of Iraqi laws would allow Tribunal to prosecute the level of destructions committed by Saddam from his presence time in Revolutionary Command Council of Iraq in 1969 to that time his regime was overthrown by United Nation (Haddadi, 2006, P. 120). Therefore, this study has been divided into two parts in order to answer the question whether it is possible to prosecute committed crimes by Baathist Regime such as war crimes after three decades passed over the end of war. First part of this paper investigates international criminal law and its approach towards Statutory Limitations because it is a debatable issue among lawyers; on the other hand, it is transformed from a domestic law to international criminal law. Second part of this study includes a list of war crimes committed by Iraq during war against Iran then the Statue of Iraqi Criminal Tribunal and its attitude toward Statutory Limitations is evaluated because this Tribunal is the only Tribunal having jurisdiction to prosecute international crimes of Iraq such as war crimes during Baath dominance on Iran.

\section{Non-recognition of Statutory Limitations in International Criminal Law}

Statutory Limitations is a legal establishment within national systems considered as a factor terminating fight and punishment as well as pardon dose. In scope of criminal law, philosophy of this establishment is forgetfulness. In other words, it is a right to be forgotten for criminal and right to forget for society. Although there are some reasons within domestic law to justify and accept Statutory Limitations, but this establishments is faced many doubts in relation with international crimes within international law. Hence, this part of study analyzes Statutory Limitations as a national establishment then it is considered in regional and international documents.

\subsection{Acceptance of Statutory Limitations in Domestic Law}

Many national laws do not consider Statutory Limitations as a factor terminating fight or punishment. Two important legal Systems Roman-Germanic and Common Law have different attitudes towards establishment of Statutory Limitations. Legal system of Roman-Germanic tends to accept Statutory Limitations while Common law Statutory Limitations are only related to civil affairs without involving in huge and severe criminal crimes. Latter approach of countries with Common law has been related to the historical and cultural reasons, because essentially Protestant culture is alien to the concept of pardon of secular sins (Delmas-Maty, 2002, P. 618). Of course, such subject is just confirmed for pardon not Statutory Limitations. There are different perspectives with

\footnotetext{
${ }^{2}$ Statutory Limitation means passage of time but it legally means passage of a determined time in which, criminal is not prosecuted or punished. Shafahi, H., (1966), Islam and rule of Statutory Limitation, first edition, Tehran, Naghsh Jahan Pub., p. 18
} 
proponents and opponents in terms of Statutory Limitations acceptance so that it can be notable to review these views. Proponents of Statutory Limitations consider the time as an important factor; According to their views, time passage can change many issues so that the public thought and conscious of society will be hurt if the crime committed long time ago is again prosecuted because society has forgotten that crime. On the other hand, passage of time can dramatically effect on effects of crime as well as evidences. Contrary to the mentioned perspective, opponents believe that time is not able to impact on the main point of issue and nature of committed crime. Hence, criminals who had committed crimes should be punished based on the justice so that victims and their families will be satisfied. If criminals are punished without considering time of commitment, the punishment will be more powerfully implemented so that public thought, conscious and awareness of society will be more towards that crime (Khaleghi, 2009, P. 122-124). Comparison of different perspectives towards Statutory Limitations indicate that principle of Statutory Limitations has been accepted in many legal systems but its acceptance and applying in criminal affairs has raised different views. Attention to various aspects of this issue demonstrates practical functions originated from the situation of Statutory Limitations in some legal systems. In legal systems with recognized Statutory Limitations, it is a principle and its non-applicability is an exception. Finally, the time duration in which, Statutory Limitations are applicable would be different in accordance with nature and severity of crime and punishment (Ruiz Farbi, Della Morte et Lambert- Abdelgawad, 2006, P. 9). The following section includes possibility or impossibility of applying Statutory Limitations in international crimes.

\subsection{Applicability or Non-Applicability of Statutory Limitations in International Crimes}

It would be a question whether national establishment of statutory limitation can be applied for international crimes or not. In domestic law, statutory limitations have raised criticisms of some philosophers of criminal law such as Beccaria (Aliabadi, 1989, P. 392) so that this establishment is cindered as a barrier to certainty of punishment (Akhoondi, 2003, P. 255). According to Beccaria, when severe crimes remaining in minds of people during a long time are proved, it is not fair they involve in statutory limitations due to the offender escape and escape from punishment (Beccaria, 1995, P. 61). Some points should be noticed to answer the mentioned question; first, traditionally, application of legal establishment of domestic system in international system has been faced many disagreements. These disagreements are raised from relations between international and national laws that its origin is associated with two famous theories of legal dualism and unity, but this study is not about to assess the relations between two systems. Second point is that instead of the obvious international documents related to the non-applicability of statutory limitations, it should be added that application of statutory limitations in relation with these crimes is not reasonable. For this reason, international criminal law has not acted similar to criminal systems so that international criminals can benefit from statutory limitations in order not to be punished. The reason for such attitude from international community is obvious that it would be against the nature of international regulations if statutory limitations were applied. Severe international crimes would hurt public opinion; hence, these crimes should be punished and suppressed. Universal jurisdiction is a type of fight against these crimes. International criminal law is about to make national authorities implement suppressive norms of treaties through universal jurisdiction. Following part of this paper is related to that time in which, international documents were silent about statutory limitations.

\subsection{Silence of International Documents about Statutory Limitations}

Formation of international criminal law has been always faced various challenges also has been a utopia than a reality. This major is considered as a new branch of public international law (Szurek, 2000, Pp. 7-22). The silence period of international rules and regulation about non-applicability of statutory limitations is related to the World War I, the time after World War II and establishment of International Military Tribunals of Nuremberg and Tokyo. There is not any point about non-applicability of statutory limitations in Treaty of Versailles 1919 that was treaty peace at the end of World War I (Mertens, 1974, P. 201). All the codified documents after World War I followed this approach to be silent about acceptance or non-acceptance of statutory limitations. Therefore, there was not any point about the issue of statutory limitations and its non-applicability in Moscow Declaration of 30 October 1943, London Agreement of 8August 1954 and Statute of Tokyo International Military Tribunal 1946. Perhaps a reason for this silence was that majority of perpetrators of committed crimes in World War II were under the dominance of Allies so that there was not any necessity to point non-applicability of time lapse. The most important document about statutory limitations in World War II is Control Council Law No. 10 of Germany adopted in 20 December 1945. According to Article 2 Claus (5), in any trial or prosecution for a crime herein referred to, the accused shall not be entitled to the benefits of any statute of limitation in respect to the period from 30 January 1933 to 1 July 1945, nor shall any immunity, pardon or amnesty granted under the Nazi regime be admitted as a bar to trial or punishment. Of course, there are many debates about coverage domain of 
this Claus while there is less doubt about two issues: first, non-applicability of statutory limitations includes crimes against humanity and second, this Article applies suspension method of statutory limitations. Articles 1 of Statute of International Military Tribunal of Nuremburg and Law No. 10 of Germany Control Council have equally identified crimes such as crimes against peace, war crimes, and crimes against humanity. As it was mentioned, Statute of this Tribunal has not been obvious about statutory limitations while Claus (5) of Article 2 of Law No. 10 has mentioned statutory limitations without direct consideration of these crimes. Herzog believes that statutory limitation should be suspended for Nazi dictatorship. The reason for such suspension is due to the lack of judicial prosecution so that the suspension would be prolonged until the bar is eliminated (Mertens, 1974, Pp. 208-209). Although perpetrators of World War II were trailed, but some of them escaped to the other countries as refugees. Hence, it was possible for these individuals to use lack of non-applicability of statutory limitations in their national law; therefore, an extensive move started in European countries during 1964 and 1965 to correct or codify the national regulations. The main purpose for such movement is related to the 20 -year time passage in respect to the end of World War II to codification of these regulations, time duration in which, the issue could be involved in statutory limitations based on the domestic rules of these countries. Hence, the silence about statutory limitations was broken when time duration extended from 20 years to 30 years and statutory limitations were completely removed from rules and regulations. This situation continued seriously through identifying non-applicability of statutory limitations in international documents. In regional and international, there are two important documents in Statute of International Criminal Court and an Article in which, non-applicability of statutory limitations has been obviously identified. These documents are evaluated in following parts of this study.

\subsection{End of World War II and Non-Applicability of Statutory Limitations in International Documents}

Convention on the non-applicability of statutory limitations to war crimes and crimes against humanity was approved in 26 November 1968 and entered into force in 11 November 1970. According to the Article 1 of this Convention, no statutory limitation shall apply to the following crimes: a) war crimes; b) crimes against humanity and genocide even if such acts do not constitute a violation of the domestic law of the country in which they were committed. Convention has clearly pointed three severe international crimes of genocide, crimes against humanity and war crimes as well as important international documents in which, these crimes are recognized. The reasons for codification of such Convention are as follows:

A) The mentioned crimes in this Convention are the severe crimes of international law. As it is pointed in title of Convention, non-applicability of statutory limitations has been directly applied for war crimes and crimes against humanity while genocide is considered at the last part of the mentioned Article of Convention 1986 so that it is not constitute in statutory limitations. Of course, genocide has been usually considered as a crime against humanity (Mertens, 1974, P. 53). According to limited definition of crimes against humanity in Statute of International Military Tribunal of Nuremburg, genocide was not considered as a crime against humanity at the time of codification of genocide convention in 1948. Statute of International Military Tribunal is the first international document has recognized crimes against humanity and emphasized on relationship between crimes against humanity and armed conflict phenomenon ${ }^{3}$. Hence, Convention 1968 is applied for three crimes of genocide, war crimes and crimes against humanity. According to importance of these crimes, the mentioned Convention has not considered any time limitation for such crimes so that it is stated at the beginning of Article 1 of this Convention "No statutory limitation shall apply to the following crimes, irrespective of the date of their commission". The literature of this sentence would extend coverage domain of convention past to as well as future. In other words, committed crimes before codification of this convention are also included.

B) Surpassing of such crimes would end their repetition so that international peace and security will increase. Fight against perpetrators of these crimes is an important factor to support human rights and fundamental freedom.

C) It would be a response to the concern of societies toward mentioned limitations in national regulations of some states. Codification of this convention would remove concern of world public opinion toward regulations of statutory limitations in terms of ordinary crimes. According to the Article 3 of this Convention, the States Parties to the present Convention undertake to adopt all necessary domestic measures, legislative or otherwise, with a view to making possible the extradition, in accordance with international law, of the persons referred to in article II of this Convention. There should be a distinguish between these crimes and ordinary crimes in domestic

\footnotetext{
${ }^{3}$ Tadic Vote of International Criminal Tribunal for the former Yugoslavia on October 2, 1995 endorsed lack of this relationship (Schabas, 2000, P. 320), criminal tribunal declared that in accordance with International Common Law, there is not necessarily a relationship between crimes against humanity and armed conflict (Prosecutor v. Dusko Tadic, 1995, P. 627)
} 
law due to the importance of these crimes. Another Convention has been codified in Europe for non-applicability of statutory limitations that is assessed in following part.

\subsection{Non-applicability of Statutory Limitations in Regional Documents}

European Convention on non-applicability of statutory limitations to crimes against humanity and war crimes 1974 was enacted in frame of Europe council actions to support human dignity. This Convention was entered into force in 27 June 2003 and has more strength points than Convention 1968. The notable point of these two International and European document is related to crimes against humanity because Convention 1974 has referred to the Convention of prevent and surpass of genocide when describes crimes against humanity; while Convention 1968 has noticed Statute of Military Tribunal of Nuremburg and resolutions of UN General Assembly in addition to the Convention on genocide 1948. Openness of European Convention is strength point of this Convention compared to Convention 1968. Although Convention 1968 has mentioned in its preamble to universal application, non-applicability of statutory limitation to war crimes and crimes against humanity, but its article 5 states that Convention is open for signature by any State Member of the United Nations or member of any of its specialized agencies. Majority of countries at the time of signing or attaching to Convention adjusted some declarations in which, it was noted that Article 5 of Convention had had considered non-applicability of statutory limitations to war crimes and crimes against humanity contrary to universal approach of this convention. Convention 1974 has not limited attachment just to the European states but any state can attach to this Convention.

A considerable point of this document is related to the mentioned rules and customs in Claus (3) of Article 1. Accordingly, each contracting state would consider any other violation of a rule or custom of international law that may hereafter be established as war crimes and crimes against humanity. Hence, the Contracting State can extend the application territory of Convention to the Claus (3) of Article 1 through addressing deceleration to the Secretary General of the Council of Europe. Therefore, Convention can extend its application territory to the relevant rules and customs of international law that may hereafter be established. Of course, implementation of this Convention to relevant rules and customs of international law is related to the addressed declaration in Article 6. The last but the most important document about non-applicability of statutory limitations is Statute of International Criminal Court assessed in following part of this paper.

\subsection{International Criminal Court and Non-Applicability of Statutory Limitations}

Contrary to statute of first generation authorities (Military Tribunals of Nuremberg and Tokyo) and two authorities of second generation (International Criminal Courts of former Yugoslavia and Rwanda), International Criminal Court has clearly mentioned the issue of non-applicability of statutory limitations. There was a silence about the issue of statutory limitations in statutes of criminal tribunals before formation of International Criminal Court. Non-applicability of statutory limitations constitutes in part III of Statute of International Criminal Law under the title of General principles of Criminal Law along with principles including legality of crimes and punishment, non-retroactivity and individual criminal responsibility. According to the content of statutory limitations, it would be wrong to consider this issue beside the other principles of general criminal law because it seems that this issue can be mentioned in terms of its acceptance. According to Article 29 of Statute of International Criminal Court, the crimes within the jurisdiction of the Court shall not be subject to any statute of limitations. There were some objections towards this Article from participant countries in Rome Conference 1998. The most important objection was related to the complementary jurisdiction of International Criminal Court identified in preamble and Article 1 of the document. This objection was imposed by countries who had accepted statutory limitations in their rules. Accordingly, complementary jurisdiction of international criminal court and non-applicability of statutory limitations have caused some problems. It would be possible to stop prosecution based on the statutory limitations and in accordance with domestic regulations while some prescription in domestic law will be affected by non- applicability of statutory limitations in statute of Court so that prosecution of issue in domestic authorities can be issued in Court. According to the proponents of statutory limitations, this would be directly against the complementary principle mentioned in the Statute if it was not mentioned in Statute (Shariat Bagheri, 2005, P. 213) because the Court can investigate the issue if it is stopped in a domestic authority in accordance with statutory limitations while such action is against the complementary principle of Court to national authorities. However, states agreed that crimes within the jurisdiction of Court should not be subject to any statute of limitations. Statute of Court, compared to the Conventions 1968 and 1974, has extended jurisdiction of Court to the war crime and military invasion in addition to genocide and crimes against humanity. This part of study was related to the assessment of International Criminal Law approach toward statutory limitations and its non-applicability. 
The following part of this paper is related to the attitude of Supreme Iraqi Criminal Tribunal toward applicability or non-applicability of statutory limitations and committed crimes of Baathist regime of Iraq specially war crimes of that regime against Iran.

\section{Supreme Iraqi Criminal Tribunal Attitude toward Statutory Limitations}

Supreme Iraqi Criminal Tribunal was created to trial Iraqi nationals or residents who were accused of war crimes, genocide, crimes against humanity and other committed crimes between during 1968 to 2003 . There are many debated around the formation of this tribunal and its jurisdictions. This part of study includes a review of committed criminal crimes by Baathist regime of Iraq against Iran, establishment of Tribunal and its jurisdiction and discussion about attitude of this Tribunal toward statutory limitations in relation with committed crimes by Baathist regime of Iraq especially war crimes against Iran.

\subsection{Review of Committed War Crimes of Iraq during Imposed war to Iran}

According to the behavior of Baath regime of Iraq toward civilian people and non-military purposes, attitude of Iraqi military forces toward Iranian combatants in different steps of war, behavior of Iraqi forces toward war prisoners from captivity time to transferring them into war camps and in accordance with the international humanitarian law, it can be mentioned that civilian people are more in danger compared to army forces during new armed invasions ${ }^{4}$. The performance of Iraqi army in war with Iran indicates that Iraqi regime that is a follower of International law did not respected regulations of international humanitarian law and used any weapon and equipment against civilian people. Use of chemical weapons during attacks to cities without any discrimination particularly aerial and aerial and missile attacks against civilian population were some illegal actions of Iraqi regime. There were 12420 killed and 53118 injured during these attacks. Inhuman treatment of Iraqi forces toward residents of occupied cities that were transferred to Iraq through murder, misbehavior and compulsory behaviors was against international humanitarian law. Attack against non-military targets such as cultural properties, non-military centers, educational centers, establishments etc. has been another Iraq's violations of international law of armed conflict. The violent behavior of Iraqi forces toward Iranian armies was as severe as that number of injured and killed individuals was declared to hundred thousand because of deadly chemical weapons (Poormohammadi, 2006, P. 230).

Execution of captives in battlefield, non-treatment of injured, killing them, misbehaviors toward defenseless captives and prisoners, physical and mental tortures are other examples of illegal actions of Iraqi regime so that mission group of then Secretary-General of the United Nations confirmed the mentioned inhuman behaviors toward Iranian war prisoners and Red Cross representatives approved the mentioned actions of Iraqi regime in their reports. Undoubtedly, the behavior of Iraqi regime toward Iranian forces was against the rules of international humanitarian law specially 1925 Geneva Protocol and third Convention and First Protocol 1977 of Geneva (Daee, 2008, Pp. 96-97).

Accordingly, the committed crimes by Iraqi army during wartime include premeditated murder of civilian people in occupied regions, torture, rape, exile the people of the occupied territories of Iran into Iraq, bombardment towns and villages, use of deadly chemical weapons, killing the wounded, execution of war prisoners in the scene of the battle, killing the captives in the camps for war prisoners, abuse of war prisoners, plundering public and private property, destruction of towns and villages, etc. According to the Claus (b) of Article 6 of Statute of Nuremburg Tribunal that its principle is confirmed through a resolution by General assembly in 1946, the mentioned actions are considered as examples of war crimes; therefore, Iraqi regime is responsible for their actions and perpetrators and criminals should be punished based on the international humanitarian law (Poormohammadi, 2006, P. 231).

The following part of this study has related to the establishment of Supreme Iraqi Criminal Tribunal and its subsequent changes.

\subsection{Establishment of Tribunal and Its Subsequent Changes}

At the beginning of the occupation of Iraq, the Iraqi Governing Council and authorities of the United States wanted the trial of Saddam within reconstructed courts of Iraq by judges who had no loyalty to Saddam (Olusanya, 2004, P. 865). In such circumstances and internal field of Iraq, temporary Governing Council of Iraq was established by coalition forces after overthrown of Baath regime in 12 Juan 2003 then the statute of Iraqi Special Tribunal was approved in 10 December 2003 in order to prosecute and trial Saddam and his forces.

\footnotetext{
${ }^{4}$ During current wars, state parties would place civilian people in danger through using modern war weapons so that humanitarian law in not respected in practice.
} 
According to the Article 1 of the Statute of Iraqi Special Tribunal, the Tribunal shall be an independent entity and not associated with any Iraqi government departments. There are various and complicated factors in evaluation of the legal nature of this Tribunal. The main factor is related to the situation of Iraq as an occupied country by coalition forces because legal base of Iraqi Special Tribunal is in in accordance with the order of occupying order This base has been challenged specially after the occupation period (Bessiouni, 2005, P. 1350). Saddam's lawyers declared that Tribunal had not have legitimacy and Saddam challenged the legitimacy of Tribunal at the first pre-session of judicial proceeding through objection toward the rule that was the base of Tribunal establishment. It might be possible that Saddam wanted to follow the reaction of Milosevic toward Tribunal for Former Yugoslavia. It might be true because one of the lawyers of Milosevic and Saddam was common; he was Ramsey Clark (former prosecutor of America) who challenged the authenticity of Tribunal (Scharf, Kang, 2005, P. 108). Many other jurists as well as Saddam and his lawyers have challenged the legitimacy of Iraqi special tribunal. They believe that occupation of Iraq caused the establishment of Special Tribunal is illegal because US occupation is illegal; hence, all the results obtained from occupation specially the establishment of Special Criminal Tribunal are out of legal effects. They assume that although Statute of this Tribunal was confirmed by Iraqi temporary Governing Council, but this Council was established buy occupying forces (Haddadi, 2006, P. 105). On the other hand, proponents of this Tribunal state that legal effects originated from military occupation can be summarized in two points as follows: 1- this occupation cannot transfer sovereignty; 2- but can distribute jurisdictions through a special method in relationships between occupier and occupied country (Haddadi, 2001, P. 35). Therefore, assumption of domination on occupied country occurs when the current entities of society are eliminated and the country is under the authority of enemy. This legal criterion will be realized if subsequent circumstances demonstrate inability of current governmental structures to conduct their power so that occupier power can do governmental tasks in occupied territory. According to the legal base of occupation, occupying power is responsible to set order and public security. It seems that this legal reason can justify the establishment of Iraqi Special Tribunal because it can complete strategic plan to prepare public peace and safe stability for civilian people of Iraq in accordance with the dominance of coalition forces (Newton, 2005, P. 154).

It can be mentioned about legal authority to official announcement of Iraqi Special Tribunal that this criterion is declaration of provisional authority of coalition that considered itself as a temporary governing entity introduced by UN Organization as legal government of Iraq until Iraq is able to politically and socially govern. Provisional authority of coalition expresses its authorities as occupier entity in Iraq as follows: provisional authority of coalition has all executive, legislative and judicial authorities to achieve its goal based on the resolution of Security Council such as Resolution 1483, rules, and customs of war ${ }^{5}$. Accordingly, provisional authority of coalition is an entity applying commitments of countries that occupy Iraq and benefiting from legal authority raised from rules and customs of war. This concept of position of provisional authority of coalition is coordinated with diplomatic statements made at establishment time ${ }^{6}$. Therefore, provisional authority was recognized as a legal entity responsible to implement commitments raised from occupation law. Resolution 1438 requests from members of provisional authority of coalition to make their commitments based on the international law such as Geneva Conventions 1949 and The Hague Regulations 1907. This Resolution is valuable in terms of establishment of Iraqi Special Tribunal because Security Council emphasizes on responsibility in relation with committed crimes by former regime of Iraq. In other words, this resolution has acted in relation with rules and customs of war in order to create positive legal power for establishment of Iraqi Special Tribunal by provisional authority of coalition (Haddadi, 2006, Pp. 113-114). Hence, Iraq special tribunal was an accurate partnership between Iraqi authorities and provisional authority of coalition that was responsible to protect rights of Iraqi people however, process of tribunal establishment was an ambiguity for world so that some supervisors criticized this tribunal because they assumed that Tribunal would obey occupying forces (Scharf, 2004, Pp. 330-331). When interim legal government of Iraq seized power tried to make the Special Tribunal as a valid and authentic tribunal in 30 June 2004 in order to confront the mentioned criticisms. Interim government took power based on the Resolution 1546 of Security Council ${ }^{7}$ and confirmed the special Tribunal allowing it to continue its task and considering it in transforming law and governmental rules of Iraq during governance of interim government. Accordingly, interim government did not put an end to jurisdiction and authority of Special Tribunal but strengthened its power through support implementation of indictments and starting interrogation sessions. Additionally, transitional government that took the power from interim government after elections, approved authenticity of Special tribunal at February 2005. Although the transitional

\footnotetext{
${ }^{5}$ Security Council Documents, Res/1483, 22 May 2003.

${ }^{6} \mathrm{~S} / 538,8$ May 2003.

${ }^{7}$ Security Council Documents, Res/1546, 8 June 2004.
} 
government did not approved legitimacy of Special Tribunal through legislation, but its Statute was approved by government through continuing to financially supply the Tribunal and allow it to continue its task. However, many assumed that transitional government should republish the statute of Tribunal through adopting an amendment rule. Republication of Statute with amendments recommended by human rights centers not only resolves the legitimacy and authenticity problem but also improves many shortcomings of human rights centers. This recommendation was conducted at August 2005, Law of the Supreme Iraqi Criminal Tribunal 2005 was substituted instead of Statute of Iraqi Special Tribunal and the title of Special Tribunal changed to Criminal Tribunal. According to Article 38 of new law of Iraqi Criminal Tribunal, all decisions and rules of procedure issued by Iraqi special Tribunal were considered legal and correct in accordance with the Statute 2003. In this regard, the best way to strengthen legitimacy of Special Tribunal was officially and unofficially validation of Iraqi Special Tribunal by the chosen government so that there was not any doubt about authority of Tribunal. Statute 2005 established by transitional national assembly could reduce concerns and possibilities in which, it was assumed that Special Tribunal had not been requested by chosen government of Iraq (Haddadi, 2006, P. 117). Therefore, Supreme Iraqi Criminal Tribunal continued its task to extend justice and trial criminals. The following part of this study includes jurisdictions of Iraqi Supreme Criminal Tribunal with emphasize on Statutory limitations.

\subsection{Subject Matter Jurisdiction}

Subject matter jurisdiction of Tribunal is a collection of international and national crimes (Article 11 to 14). The considered crimes in Articles 11 to 14 are as follows: genocide, crimes against humanity, war crimes and violation of Iraqi laws. Statute of Iraqi Supreme Criminal Tribunal has been adopted from statute of International Criminal Court and International Criminal Tribunal for Rwanda in terms of international crimes. Supreme Tribunal would be a domestic judicial entity with international members because of crimes under the jurisdiction of Tribunal to investigate them and apply international law in this field (Bantekas, 2005, P.241).

A) Genocide: Article 11 of Statute of Tribunal is related to crime of genocide. Claus (1) of Article 11 is coordinated with Article 6 of Statute of International Criminal Court but two clauses of the Article are similar to Article 2 of Statute of International Criminal Tribunal for Rwanda. According to Clause (1) of Article 11, Iraq is member of Convention on the Prevention and Punishment of the Crime of Genocide 1948. It would be expected to apply this Article about persecution of Kurds and Shiites. Nevertheless, Convention on genocide 1948 only supports victims of groups of national, ethnic, racial or religious and considers members of political group as exception. As a result, this Article can be issued about crimes against Kurds with different races (Sunni Arab) (Olusanya, 2004, P. 871) while this Article cannot be applied for Shia because they are Muslims and Arabs like Sunnis. However, genocide is the worse crime so that is called "crime of crimes" (Shebth, 2005, P. 46).

B) Crimes against humanity: Article 12 of Statute of Iraqi Supreme Criminal Tribunal is related to crimes against humanity. This Article has repeated content of Article 7 of Statute of International Criminal Court. The issue is not considered in Article 12 is legality principle of crime and punishment. In previous Article, Iraq is was member of the Convention on genocide so there was not any problem to enforce that Principle while the legal state of recognized crimes against humanity based on the Article 12 during 1968 to 1990 is not clear (Olusanya, 2004, P. 868).

C) War crimes: Article 13 of Statute is coordinated with Article 8 of Statute of International Criminal Court and Article 30 of draft code 1996 of crimes against peace and human security. The similarity between these provisions is based on this fact that Article 13 includes a similar list of war crimes like the list of mentioned Article. Like Article 12, it is objected toward Article 13 that legality of crime is violated because other violation of rules and customs of war (Common Article 3 and Amendment Protocol 2) had no legal state until 1990 (Haddadi, 2006, P. 122). According to the assessments about complaint of Iran against Saddam, it was determined, regardless of the imposed war and violation, conducted actions by Saddam and army leaders against Iran are included in war crimes. Although there are other dubious case, but some violent actions especially at the start of war such as mass deportation of Iranian-born Iraqis from Iraq and misbehaviors towards girls and women in Khuzestan occurred in the first weeks of the war indicated that some of this events might not be coordinated with definitions of crimes against humanity. According to the Statute of Iraqi Tribunal and its jurisdiction, what is related to Iran is that conventions between Iran and Iraq are enforceable and Iranian party should declare the considered crime committed by Saddam and his regime that are included in war crimes. As it was mentioned, all the cases involves in national and international jurisdictions because Iran and Iraq are both members of four Geneva Conventions in which, they are responsible to investigate war criminals so that this issue can be considered in any case. 
D) Violation of Iraqi laws: Article 14 of Statute would give power to prosecute persons who have committed the following crimes: 1- interference in the affairs of the judiciary or attempting to influence its functioning. 2- the wastage and squandering of national resources, pursuant to Article $2(\mathrm{G})$ of the Punishment of Conspirators against Public Safety and Corrupters of the System of Governance Law 7 of 1958. 3- the abuse of position and the pursuit of policies that have almost led to the threat of war or the use of the Iraqi armed forces against an Arab country, in accordance with Article 1 of Law 7 of 1958. According to Clauses 1 and 2 of Article 14, it seems that crimes are national while clause 3 would accept encroachment from the national view (Haddadi, 2006, P. 123).

\subsection{Personal Jurisdiction}

Personal jurisdiction of Supreme Iraqi Criminal Tribunal has been determined in clause 2 of article 1 of Statute in which, Tribunal shall have jurisdiction over every natural person, whether Iraqi or non-Iraqi resident of Iraq. This article confirms criminal nature of Tribunal at first and then determines personal jurisdiction such as prosecution of individuals not organizations, entities and legal individuals. Criminal nature of Tribunal is based on the loyalty to legality principle of prosecution and punishment of accused persons. The Tribunal has jurisdiction to investigate crimes of natural not legal persons as well as the jurisdiction of International Criminal Court (Article 25). Although there have been efforts to extend this jurisdiction to committed crimes by legal persons, but these efforts have not been successful (Mir Mohammad Sadeghi, 2009, P. 137).

\subsection{Territorial Jurisdiction}

Territorial jurisdiction of Supreme Iraqi Criminal Tribunal has been mentioned in clause (2) of Article 1. According to the coverage domain of territory, Statute of Tribunal would allow Tribunal to prosecute Saddam and his state members due to their committed crimes in Iraq or elsewhere including committed crimes in relation with war against Iran and Kuwait. All the committed crime by Saddam and his state members during Baath regime can be included in one of these categories; those crimes toward Iraqi people or even toward their neighbors, Iran, Kuwait and their residents. In addition to international crimes mentioned in Statute of Iraqi Tribunal, Article 14 of this Statute about violation of some Iraqi law and jurisdiction of Tribunal over them including wastage and squandering of national resources, interference in the affairs of the judiciary, threat of war or the use of the armed forces against an Arab country. The expressions of threat, armed attack or enforcement to an Arab country attract the attention. At the time of codification of this document, it was considered to place the armed attack against Kuwait under the jurisdiction of Tribunal while there is not any point about flagrant and confirmed aggression by the United Nations against Iran within Statute and this issue is apparently silent (Siah Rostami, 2004, Pp. 212-213).

\subsection{Non-applicability of Statutory Limitations in Supreme Iraqi Criminal Tribunal}

Non-applicability of statutory limitations of Statute of Supreme Iraqi Criminal Tribunal. Accordingly, the Tribunal shall have jurisdiction over every natural person, whether Iraqi or non-Iraqi resident of Iraq, accused of committing any of the crimes committed during the period from 17 July 1968 to 1 May 2003, in the Republic of Iraq or elsewhere, including committed crimes in relation with Iraq-Iran war and Iraq-Kuwait war. This Article has determined 35-years duration as time limitation from 1968 to 2003 for Iraqi Tribunal. Therefore, this Claus has clearly determined and proved non-applicability of statutory limitations regarding committed war crimes by Iraq against Iran. Although this duration is more extensive than time duration of International Criminal Tribunal for Yugoslavia (from 1991), the International Criminal Tribunal for Rwanda (only one year) and the Special Court for Sierra Leone (starting from 30November 1996), but it is not comprehensive. Although criminalization and committed crimes by Saddam during 16 July 1968 to 1 May 2003 would enable Tribunal to investigate all committed crimes by Saddam from his power in Iraqi Baathist Revolutionary Command Council to overthrown of his governance by UN and coalition forces in 2003 as well as other criminals (war crimes against Iran), the opposed meaning of this Claus of Article 1 is that committed crimes after 1 May 2003 (such as committed crimes by US military forces and military forces of coalition in Abu Ghraib Prison) are not prosecutable by Iraqi Tribunal because they have occurred after March and November 2003. It seems that Supreme Tribunal is not able to exercise its jurisdiction over crimes committed by coalition forces before 1 May 2003 while these forces were under the jurisdiction of their government. One of the first issued instructions by Coalition Provisional Authority states that coalition forces are immune from legal and prosecution processes of Iraq $^{8}$. According to this legal system, non-Iraqi judicial processes would determine the actions of coalition forces creating crime. For instance, an American military force must follow international laws including four Conventions of Geneva, and

${ }^{8} \mathrm{CPA} / \mathrm{ORD} / 20$ June 2003; CPA/MEM/18 June 2003. 
relevant American rules such as uniform rules of military justice; hence, judgment of any violation should be done by American military tribunals. Therefore, an Iraqi is not able to complaint to an Iraqi police or Tribunal about an illegal arrest or torture so the only solution is to referral to a foreign tribunal. On the other hand, Resolution 511 of UN Security Council would allow Iraq to have multi-national forces in order to extend stability in Iraq ${ }^{9}$. According to Clause 15 of this Resolution, the mandate of the force shall expire upon the completion of the political process and return of sovereignty to the Iraqis. If the date of 1 May 2003 were not mentioned as the end of time jurisdiction in Statute of tribunal, this tribunal would be ability to exercise its jurisdiction over the foreign military forces committed crimes after the mentioned date (Farrokhi Hoodar, 2006, P. 136). Therefore, this approach is in an obvious conflict with other approaches of executive entities of international criminal law. For instance, International Criminal Tribunal for Yugoslavia has jurisdiction without any time limitation based on Article 1 of its Statute that states international tribunal has jurisdiction to prosecute persons for "grave breaches" against international humanitarian laws in former Yugoslavia from 1991 and in accordance with provisions of Statute. Contrary to this Statute, Statute of Rwanda is similar to the Statute of Iraq with same provisions. Article 1 of Statute of International Criminal Tribunal for Rwanda has limited jurisdiction of this Tribunal to first January 1994 to 31 December of the same year. Statute of the Special Court for Sierra Leone has an approach similar to the approach of International Criminal Tribunal for Yugoslavia. According to Clause (1) of Article 1 of this Statute, Tribunal has the power to prosecute persons who bear the greatest responsibility for serious violations of international humanitarian law and Sierra Leonean law committed in the territory of Sierra Leone since 30 November 1996.

3.6.1 Following Part of This Paper Is Related to Conflict between Statutory Limitations in Supreme Iraqi Criminal Tribunal and Principle of Legality of Crime

Another aspect of statutory limitations in Statute of Supreme Iraqi Criminal Tribunal is related to the conflict between this issue and principle of legality of crime; because, firstly, legal system of Iraq does not have criminal titles and descriptions mentioned in Statute and many of the mentioned crimes in Statute do not exist in rules and regulations of Iraq; secondly, it is not clear that international crimes such as crimes against humanity and war crimes mentioned in Articles 12 and 13 during 1968 to 1990 (Daphna, Ralph, 1994, Pp.4-5) have common legal features as it is declared in these regulations (Crawford,1994, P. 148). In granting power to International Tribunal for Rwanda to prosecute persons who are responsible for violation of common Article 3 of Geneva Conventions and Article 4 of Additional Protocol II, Security Council preferred to follow open criterion with less limitation than approved criterion in International Criminal Tribunal for Yugoslavia to select applicable laws and regulations. It should be mentioned that Yugoslavia Court had power to exercise regulations having nature of international common law and criminal responsibility for war committed while International Criminal Tribunal for Rwanda had power to exercise provisions of Additional Protocol II were not recognized as a part of common international law from the perspective of world community and criminalized the common Article 3 of Geneva Conventions 1949 for the first time. Hence, it can be concluded that violations of rules and customs of war at the time of establishment of International Criminal Tribunal for Rwanda could not form common international law. Hence, it seems that Article 12 and 13 of Statute of Supreme Iraqi Tribunal during 1968 to 1990 are in conflict with principle of legality of crime (Farrokhi Hoodar, 2006, P. 138). The procedure of other criminal tribunals is assessed in following part of study.

\subsubsection{Applicability or Non-Applicability of Statutory Limitations in Other Criminal Tribunals}

As it was mentioned, there was a silence about statutory limitations in Military Tribunals including Nuremberg and Tokyo and International Criminal Tribunals for former Yugoslavia and Rwanda. This part of study is related to the approach of other criminal tribunals in accordance with different approaches toward international crimes based on the applicability or non-applicability of statutory limitations. The issue of statutory limitations was proposed in cases of Barbie and Tovieh in France and Pribke and Hues in Italy. There is a dualism in law of France toward crimes against humanity and its acceptance in war crimes while Italian tribunals denied the issue of statutory limitations for crimes against humanity and war crimes in case of Pribke and Hues. Government of France proposed the insertion of Article 124 in Rome Statute at the time of Rome Conference 1998 so that its approach was accepted. According to this Article, war crimes of Article 8 of Statute were extracted from jurisdiction of Tribunal for seven years after the entry into force. Participation of forces of France within peace operations and their presence at any place of world was another emphasized reason in order to support its forces through prosecution of committed war crimes (Dobelle, 2000, Pp. 760 - 762).

On the other hand, based on Articles 4 and 5 of Cambodia Act 2000 about establishment of extraordinary

\footnotetext{
${ }^{9}$ Security Council Documents, Res/1511, 16 Oct 2003
} 
branches in Tribunals of Cambodia to prosecute committed crimes at the time of democratic Cambodia, genocide and crimes against humanity are not involved in statutory limitations while Article 3 of this Act has extended 20-years statutory limitations of Penal Code 1956 for suicide, torture and mass persecution based on the religious bases (kesseh, 2008, P. 400).

\section{Conclusion}

According to international law, use of force, threat or use of force against the independence and territorial integrity that is inconsistent with the purposes of the United Nations is prohibited and the only exception to that right is self-defense and enforcement measures under the Chapter VII of the UN Security Council. Iraqi government tried to justify its extensive invasion against Iran as a self-defense that was against alleged attacks of Iran against borders of Iraq and lack of respect to water borders in Shatt Al Arab. Although international community or Security Council refused to accept aggression of Iraq, but this Council did not confirmed claims of Iraq. Crimes committed by Iraq during war against Iran were rare; there were also many violated rules and regulations of international law and humanitarian principles as well as material and spiritual harms for Iran and Iranian people without any effective reaction from international community. The mentioned injustice should not be a way for criminals and responsible not to take the responsibility because as it was discussed, it would be possible to ask criminals of war to take their responsibilities despite the long time passed since the end of the war. These crimes are not supposed to prescription since one important activities of international community is to fight against impunity through non-applicability of statutory limitations for international crimes. Hence, statutory limitations as well as other actions such as pardon and forgiveness cannot be an excuse not to prosecute or punish international criminals. Non-applicability of statutory limitations has been considered in various documents including Statute of International Criminal Court 1998 and Statute of Supreme Iraqi Criminal Tribunal established in order to investigate crimes by leaders of the Baath regime. The Tribunal considered retroactive jurisdiction to investigate committed crimes by Iraqi leaders for 35-years before the establishment of the court. This issue indicates the international community's determination to suppress international crimes as a big step towards eliminating impunity.

\section{References}

Akhoondi, M. (2003). Code of Criminal Procedure (2nd ed.). Tehran, Printing and Publishing Ministry of Culture and Islamic Guidance.

Ali Abadi, A. (1988). Criminal Law (Vol II, 1st ed.). Tehran, Ferdosi Pub.

Bantekas, L. (2005). The Iraqi Special Tribunal for Crimes Against Humanity. ICLQ, 54(1). http://dx.doi.org/10.1093/iclq/54.1.237

Beccaria, C. (1995). Treatise of crimes and punishments (Mohammad Ali Ardebili Trans, 2nd ed.). Tehran, Shaheed Beheshti University.

Bessiouni, M. C. (2005). Past- Conflict Justice in Iraq Special Tribunal. Cornell International Law Journal, $38(2)$.

Control Council Law No, 10, 1945.

Convention on the non-applicability of statutory limitations to war crimes and crimes against humanity, 1968.

CPA/MEM/18 June 2003.

CPA/ORD/20 June 2003.

Crawford, J. (1994). The ILC"s Draft Statute for an International Criminal Trbunal. American Journal of International Law, 88(1). http://dx.doi.org/10.2307/2204031

Daei, A. (2008). international responsibility for violating the rights of Iranian prisoners of war in Iraq. International Journal of Law, (38).

Dekker, I. F. (1992). Criminal Responsibility and the Gulf War of 1980-1988: The Crime of Aggression In Dekker, \& H. Post (Eds.), The Gulf War of 1980-88. Geneva, Martinus Nijhoff.

Delmas-Marty, M. (2002). La responsabilite penale en echec (prescription, amnistie, immunites). In Cassese, A. (Eds.), Juridictions nationales et crimes internationaux. Paris, Puf. http://dx.doi.org/10.3917/puf.delm.2002.01.0613

Dobelle, J. F. (2000). Pratique francaise du droit international 2000. Annuaire francais de droit international, 46. http://dx.doi.org/10.3406/afdi.2000.3643 
Doroodian, M. (1997). investigate the causes of the inevitability of Iraq-Iran war. Defense Policy magazine, (19).

European Convention on the non-applicability of Statutory Limitations to crimes against humanity and war crimes was, 1974.

Farokhi Hoodar, M. (2006). The Iraqi Special Tribunal in the light of international criminal law. lecturer in humanities, (47).

General Assembly Documents, Res/95, 11 Dec 1946.

Haddadi, M. (2006). verify the legitimacy of the Iraqi Special Tribunal (Supreme Iraqi Criminal Tribunal). Legal Thought, (11).

Hume, C. (1997). the United Nations, Iran and Iraq, Hooshang Rasekhi Azmi Sabet Trans, Tehran, Institute for Political and International Studies.

International Criminal Court (ICC), 1998.

Kesseh, A. (2008). international criminal law (Hussein Piran et al Trans, 1st ed.). Tehran, Jangal Pub, Javedaneh.

Khaleghi, A. (2009). Code of Criminal Procedure (1st ed.). Tehran, MIZAN Pub.

Law of the Supreme Iraqi Criminal Tribunal, 2005.

Mertens, P. (1974). L'imprescriptibilite des crimes de guerre et contre I'humanite, Bruxelles, Editions de 1' Universite de Bruxelles.

Mir Mohammad Sadeghi, H. (2009). the International Criminal Court (5th ed.). Tehran, Press Institute of Justice.

Newton, M. A. (2005). The Iraqi Special Tribunal: A Human Rights Perspective. Cornell International Law Journal, 38(3).

Noorbaha, R. (1992-1993). protection of cultural property during armed conflict and contract review its actions in the war against Iran. Journal of Law, (16-17).

Olusanya, O. (2004). The Statute of the Iraqi Special Tribunal for Crimes Against Humanity- Progressive or Regressive? German Law Journal, 5(7).

Paenson, I. (1989). Manual of Terminology of the Law of Armed conflicts and of International Humanitarian Organization, (Martinus Nijhoff).

Parsadoost, M. (1992). the role of the United Nations in Iran-Iraq war. Tehran, joint-stock company pub.

Pour Mohammadi, N. (2006). humanitarian law in the war between Iran and Iraq: browsing Iraq's behavior (1st ed.). Tehran, Center for Studies and Research War.

Prosecutor v. Dusko Tadic, IT-94-1-AR72, Appeals Chamber, Decision, 2 October 1995.

Quoc Dinh, N. et al. (1994). Droit international public (5 $5^{\text {th }}$ ed.). Paris, L.G.D.J.

Ruiz Farbi, H. et al. (2006). Les institutions de clemence en Europe. Archive de Politique Criminelle, (28).

S/538, 8 May, 2003.

Schabas, W. A. (2000). "Le genocide" in droit international penal, sous la dir, Ascensio, H, Decaux, E, Pellet, A, Paris, Pedone.

Scharf, M. P. (2004). Is It International Enough?: A Critique of the Iraqi Special Tribunal in Light of the Goals of International Justice. Journal of International Criminal justice, 2(2). http://dx.doi.org/10.1093/jicj/2.2.330

Scharf, M. P., \& Kang, A. (2005). Errors and Missteps: Key Lessons the Iraqi Special Tribunal Learn from the ICTY, ICTR, and SCOL. Cornell International Law Journal, 38(3). http://dx.doi.org/10.2139/ssrn.804607

Security Council Documents, Res/1483, 22 May 2003.

Security Council Documents, Res/1511, 16 Oct 2003.

Security Council Documents, Res/1546, 8 June 2004.

Security Council Documents, Res/598, 20 July 1987.

Shafahi, M. (1966). Islam and the statute of limitations (1st ed.). Tehran, Naghsh Jahan Pub.

Shariat Bagheri, M. J. (2005). international criminal law (1st ed.). Tehran, Jangal Pub. 
Shebth, W. (2005). Introduction to the International Criminal Court, Seyyed Bagher Miaabbasi and Hamid Elahavi Nazari, Tehran, Jangal Pub.

Shraga, D., \& Zacklin, R. (1994). International Criminal Tribunal for the Former Yugoslavia. European Journal of International Law, 5(3).

Siah Rostami, H. (2004). the trial of Saddam Hussein and analysis of the positions of the Islamic Republic of Iran. International Studies Quarterly, (3).

Szurek, S. (2000). "La formation du droit international penal" in droit international penal, sous la dir, Ascensio, H, Decaux, E, Pellet, A, Paris, Pedone.

The Statute of the Iraqi Special Tribunal, 2003.

Vahedi, Gh. (2001). issues of international criminal law: crimes committed in the occupied territories. Tehran, MIZAN pub.

Zamani, S. G. H. (2002). the humanitarian law and occupation of Iran in the war. Tehran, Shahr Danesh Pub.

\section{Copyrights}

Copyright for this article is retained by the author(s), with first publication rights granted to the journal.

This is an open-access article distributed under the terms and conditions of the Creative Commons Attribution license (http://creativecommons.org/licenses/by/3.0/). 